American Journal of Pharmaceutical Education 2020; 84 (8) Article 7892.

\title{
COMMENTARY
}

\section{Joint Statement on Pediatric Education at Schools of Pharmacy}

Christina L. Cox, PharmD, ${ }^{\mathrm{a}}$ Timothy J. Todd, PharmD, ${ }^{\mathrm{b}}$ Lisa Lubsch, PharmD, ${ }^{\mathrm{c}}$

Kristin C. Klein, PharmD, ${ }^{d}$ William A. Prescott, Jr., PharmD, ${ }^{\mathrm{e}, \mathrm{m}}$ Chad A. Knoderer, PharmD, ${ }^{\mathrm{f}}$

Peter N. Johnson, PharmD, ${ }^{\mathrm{g}}$ Rachel Meyers, PharmD, ${ }^{\mathrm{h}}$ Justin W. Cole, PharmD, ${ }^{\mathrm{i}}$

Joseph M. LaRochelle, PharmD, ${ }^{\mathrm{j}}$ Mary A. Worthington, PharmD, ${ }^{\mathrm{k}}$ Katherine Smith, PharmD ${ }^{1}$

${ }^{a}$ University of South Carolina, College of Pharmacy, Columbia, South Carolina

${ }^{\mathrm{b}}$ Midwestern University Chicago, College of Pharmacy, Downers Grove, Illinois

${ }^{\mathrm{c}}$ Southern Illinois University Edwardsville, School of Pharmacy, St. Louis, Missouri

${ }^{\mathrm{d}}$ University of Michigan, College of Pharmacy, Ann Arbor, Michigan

${ }^{\mathrm{e}}$ University at Buffalo, School of Pharmacy and Pharmaceutical Sciences, Buffalo, New York

${ }^{\mathrm{f}}$ Butler University, College of Pharmacy and Health Sciences, Indianapolis, Indianapolis

${ }^{g}$ University of Oklahoma, College of Pharmacy, Oklahoma City, Oklahoma

${ }^{\mathrm{h}}$ Rutgers University Ernest Mario, School of Pharmacy, Piscataway, New Jersey

${ }^{\mathrm{i}}$ Cedarville University, School of Pharmacy, Cedarville, Ohio

${ }^{\mathrm{j}}$ Xavier University of Louisiana, Louisiana State University Health Sciences Center, School of Medicine, New Orleans, Louisiana

${ }^{\mathrm{k}}$ Samford University McWhorter, School of Pharmacy, Birmingham, Alabama

${ }^{1}$ Roseman University of Health Sciences, College of Pharmacy, South Jordan, Utah

${ }^{\mathrm{m}}$ Editorial Board Member, American Journal of Pharmaceutical Education, Arlington, Virginia

Submitted October 21, 2019; accepted February 4, 2020; published August 2020.

Providing health care for children is a unique specialty, and pediatric patients represent approximately $25 \%$ of the population. Education of pharmacy students on patients across the lifespan is required by current Accreditation Council for Pharmacy Education standards and outcomes; thus, it is essential that pharmacy students gain a proficiency in caring for children. A collaborative panel of pediatric faculty members from schools and colleges of pharmacy was established to review the current literature regarding pediatric education in Doctor of Pharmacy curricula and establish updated recommendations for the provision of pediatric pharmacy education. This statement outlines five recommendations supporting inclusion of pediatric content and skills in Doctor of Pharmacy curricula.

Keywords: pediatric, pharmacy, education

\section{INTRODUCTION}

In 2005, the Pediatrics Practice and Research Network (PRN) of the American College of Clinical Pharmacy (ACCP) published an opinion paper that provided recommendations for pediatric content in schools and colleges of pharmacy in the United States and Canada. ${ }^{1}$ In this paper, the Pediatrics PRN recommended that all pharmacy programs offer a minimum of 25 contact hours of didactic instruction in pediatrics, that elective courses in pediatrics are available and provide 16-32 contact hours, and that all students have access to at least one pharmacy practice experience in the area of pediatrics. To guide curricular development and revision, the ACCP

Corresponding Author: Christina L. Cox, University of South Carolina, College of Pharmacy, 715 Sumter St., Columbia, SC. Tel: 803-777-1947. Email: coxcl@cop.sc.edu
Pediatrics PRN provided a list of 28 pediatric subject areas for inclusion in core and/or elective curricula and advised that these pediatric topics be taught by pediatric content experts whenever possible. ${ }^{1}$ These recommendations, now more than a decade old, lack discussion on integration into skills courses and do not account for more recent pediatric pharmacotherapy and guideline updates.

The pediatric age group accounts for approximately one-quarter of the United States population. ${ }^{2}$ In those under 18 years of age, overall rates of outpatient health care visits are increasing and exceed rates in adults aged 19 to 64 years. ${ }^{3}$ Furthermore, $70 \%$ of all visits to pediatric practices include the mention of a medication, ${ }^{4}$ a number that has increased over time. Regarding medication use, approximately $22 \%$ of children in the United States receive a prescription medication each month. ${ }^{3}$ Pharmacists 


\section{American Journal of Pharmaceutical Education 2020; 84 (8) Article 7892.}

are therefore very likely to encounter pediatric patients in their daily practice, whether in the inpatient or outpatient setting.

In addition to contributing significantly to health care visits and prescriptions, pediatric patients are three times more likely to experience a medication error than adult patients. ${ }^{5}$ This is primarily because of pharmacokinetic differences between children and adults, limited availability of pediatric-friendly dosage forms, lack of standardization in dosing and medication concentrations, inconsistent dosing devices, and calculation errors because of the need for weight-based dosing. These dosing errors may be due to inaccurate or outdated patient weights, transcription errors when documenting weights in a child's health record, or documentation of incorrect weight units (ie. kilograms and pounds). A 2015 survey of community pharmacists found that only $31 \%$ reported checking doses for pediatric prescriptions fairly often, nearly always, or always. ${ }^{6}$ Medication safety issues are compounded by the lack of well-designed studies in children. Although regulatory changes, including the 2002 Best Pharmaceuticals for Children Act (BPCA), ${ }^{7}$ the 2003 Pediatric Research Equity Act (PREA), ${ }^{8}$ the 2012 Food and Drug Administration Safety and Innovation Act (FDASIA), ${ }^{9}$ and the 2017 Research to Accelerate Cures and Equity (RACE) for Children $\mathrm{Act}^{10}$ have made significant strides in protecting children, less than $50 \%$ of medications are labeled for use in children and lack pediatric-specific information, including dosing, efficacy, and safety. ${ }^{11}$ Additionally, over the last 15 years, the Food and Drug Administration (FDA) has received 1200 pediatric studies, and over 700 medication labels have been changed. ${ }^{12}$ Because this has potential implications on the safe and effective use of medications in the pediatric population, it highlights the importance of ensuring all pharmacy graduates are competent for entry-level positions in which they will care for pediatric patients. Pharmacy curricula should emphasize each of these unique aspects of caring for children.

A survey conducted nearly a decade after the publication of the first ACCP Pediatrics PRN opinion paper demonstrates that there are still opportunities to improve the preparation of pharmacy graduates to deliver basic care to pediatric patients. ${ }^{13}$ The 2013 survey of accredited and candidate-status US pharmacy programs revealed that $94 \%$ of respondents include pediatric topics as part of their required curricula; however, the median number of contact hours is 16 , well below the 25 hours recommended in the 2005 paper. ${ }^{1,13}$ Only $61 \%$ of pharmacy programs offer a pediatrics elective; and while $97 \%$ of respondents report offering pediatric advanced pharmacy practice experiences (APPEs), only $20 \%$ of eligible students complete a pediatric
APPE. Additionally, although the survey indicated that schools have, on average, two full-time and two adjunct faculty members specializing in pediatrics who can provide pediatric content or APPEs, only $75 \%$ of all programs employ a full-time pediatric faculty member. This highlights the need to readdress the initial recommendations of the 2005 opinion paper.

\section{METHODS}

Pediatric faculty members of the American Association of Colleges of Pharmacy (AACP) Pediatric Pharmacy Special Interest Group (SIG), American College of Clinical Pharmacy (ACCP) Pediatrics Practice and Research Network (PRN), and Pediatric Pharmacy Association (PPA) recognized the need for collaboration in order to provide educators with consensus recommendations on pediatric content and skills in Doctor of Pharmacy (PharmD) curricula. Members from each organization served as the initial discussion group and guided author selection. Because the PPA has the largest membership of pediatric pharmacy practitioners and many of its members are members of at least one of the other organizations, author recruitment was conducted electronically through the PPA academic SIG. Interested contributors were asked to submit their curricula vitae, which were subsequently reviewed for consideration. Purposeful selection of authors included that they meet the following requirements: they were an academician at the rank of associate professor or professor; were a member in at least two of the participating organizations; and had a sustained record of achievement in the area of pediatric education and/or pharmacy practice. The collaborative panel included 12 academic members, four from each organization to ensure equal representation. No conflicts of interest were identified among the authors.

After finalizing and convening the panel, three task forces were formed to address the major needs of the project, which included: a literature evaluation pertaining to pediatric pharmacy and education, current fulfillment of the Accreditation Council for Pharmacy Education's (ACPE) 2016 Standards for the PharmD degree ${ }^{14}$ by pediatric content, and pediatric pharmacy curricular recommendations. Each task force was comprised of members representing at least two organizations and met via webbased teleconferences or electronically to ensure full participation without geographical or logistical barriers. The literature evaluation task force, comprised of six members, was provided a set list of discussion points compiled by the panel. Special assignment was considered for authors having completed work in a respective interest area. Each member of this task force individually conducted a PubMed search and submitted published manuscripts, abstracts, or other relevant position statements to a shared 


\section{American Journal of Pharmaceutical Education 2020; 84 (8) Article 7892.}

electronic repository. Each reference was placed into one of seven categories: pediatric patient care (general), pediatric education, pharmacy, other health professions, pediatric pharmacy role in patient care, pediatric diseases into adulthood, or other. Articles were summarized and reviewed by at least two task force members to ensure relevance and accuracy.

A task force of three members reviewed the ACPE Standards 2016 and the Center for the Advancement of Pharmacy Education (CAPE) Outcomes 2013. ${ }^{14,15}$ After compiling a list of elements from the Standards 2016, each member of the task force individually evaluated the relevance of each element to pediatric pharmacy practice. Consensus on the relevance of each element in Standards 2016 was achieved among the members of the task force. Additional feedback was solicited from the panel, discussed within the task force, and incorporated into the final list of ACPE Standards 2016 and CAPE outcomes that relate to pediatric pharmacy practice.

A three-member task force developed an initial list of pediatric pharmacy topics based on previously published recommendations and various educational studies. ${ }^{1,16,17}$ The final list of pediatric pharmacy topics was decided by unanimous vote between the three members of this task force. The topic list was then sent to the panel for comment and approval. After comments were received, the list of pediatric core topics that every graduating pharmacist should be exposed to during their required PharmD curricula was finalized (Tables 1 and 2). This list was then stratified into topics that, based on the level of expertise required, could be covered by either pediatric-trained or non-pediatric trained faculty members.

Upon completion of the panel-approved recommendations and manuscript draft, an open-comment period was provided to each organization using Dotstorming, an online group-sharing and decision-making tool. Members of the PPA, the ACCP Pediatrics PRN, and the AACP Pediatric Pharmacy SIG were asked to vote and comment on each of the five recommendations. Feedback was discussed by the panel and incorporated into the final draft accordingly. The final recommendations were distributed to the following for a vote: AACP Pediatric Pharmacy SIG, ACCP Pediatrics PRN, and PPAG Board of Directors. Upon approval from each of the groups listed, the joint statement was submitted for publication. Final recommendations are included in Table 3.

\section{REVIEW AND RECOMMENDATIONS}

All graduates of an accredited pharmacy program should be able to meet the basic educational outcomes specified by ACPE at an appropriate entrustable professional activity (EPA) competency level, regardless of the patient population with which they are working. Standard 2 describes "essentials for practice and care," and includes patient-centered care and population-based care. ${ }^{17}$ Historically, medications are approved with limited to no information regarding dosing, safety, or efficacy in pediatric patients; therefore, pharmacy graduates must be able to interpret patient information and apply available scientific data to pediatric patient populations to ensure safe and effective use of medications in children (ACPE standard 25.7, CAPE outcomes 2.1 and 2.4). Of equal importance is proficiency in communication with children and their caregivers, including patient education (ACPE standard 3.6, CAPE outcomes 3.2 and 3.6). The skills necessary to educate or communicate with a young child and his/her adult caregiver or an adolescent who is starting to assume some responsibility for his/her health care are vastly different but no less important than those needed to communicate with someone who has a low health literacy or who does not speak English as their first language. In addition to meeting ACPE educational outcomes, in 2017 the American Association of Colleges of Pharmacy published pharmacy-specific EPAs that colleges are expected to incorporate throughout the required PharmD curriculum. ${ }^{18}$ The Association of American Medical Colleges originally outlined EPAs as "units of professional practice, defined as tasks or responsibilities that trainees are entrusted to perform unsupervised once they have attained specific sufficient competence." 19 Entrustable professional activities are subdivided by the level of supervision required by the student, from level 1 where the student observes a task, through level 5, where the student is able to teach others. For students to develop the baseline knowledge, skills, and attitudes necessary to care for children at an expected EPA competency level, pediatric education must be intentionally integrated into didactic and experiential pharmacy curricula.

\section{Didactic Education}

The pharmaceutical care needs of patients differ greatly based on age, from prenatal care through adulthood. This idea of the provision of "care across the lifespan" is central to ACPE Standards 2016. For students to develop the knowledge and skills necessary for the care of children, pediatric content must be integrated into all aspects of the didactic curriculum, including biomedical, pharmaceutical, clinical, social/administrative/behavioral sciences, and clinical sciences (ACPE Standard 12.4). Didactic instruction should address changing human physiology throughout childhood development, common conditions unique to pediatric patients, calculations pertinent to pediatric medication therapy, and social and behavioral aspects that influence a child's health. Tables 1 


\section{American Journal of Pharmaceutical Education 2020; 84 (8) Article 7892.}

Table 1. Recommended Pharmacy Curricula Pediatric Topics to Be Included in the Didactic Portion of the Curricula for the Doctor of Pharmacy Program

\begin{tabular}{|c|c|c|}
\hline System & $\begin{array}{c}\text { Should Be Taught by } \\
\text { Pediatric-Trained Faculty }\end{array}$ & $\begin{array}{c}\text { Could Be Taught by Non-Pediatric } \\
\text { Trained Faculty Member }\end{array}$ \\
\hline General & $\begin{array}{l}\text { Anatomical differences in the pediatric population } \\
\quad \text { (including growth and development, vital signs, etc) } \\
\text { Calculations (Dosing, } \mathrm{CrCl} \text {, etc) } \\
\text { Communication skills } \\
\text { Medication safety (Prescriptions risks, technology, etc) } \\
\text { Pharmacokinetic/Pharmacodynamic differences } \\
\text { Dosage forms } \\
\text { Drug information sources for pediatrics } \\
\text { Fever }\end{array}$ & $\begin{array}{l}\text { Medication adherence specific to pediatrics } \\
\text { Toxicology/Poison prevention specific to pediatrics } \\
\text { Consent and assent/Research } \\
\text { Pharmacogenomics }\end{array}$ \\
\hline Neurology & $\begin{array}{l}\text { Pediatric seizures (eg, febrile seizures, infantile } \\
\text { spasms) } \\
\text { Ketogenic diet }\end{array}$ & \\
\hline Psychiatry & $\begin{array}{l}\text { Attention deficit hyperactivity disorder } \\
\text { Autism spectrum disorder }\end{array}$ & Depression \\
\hline Pulmonology & Cystic fibrosis & Asthma \\
\hline Cardiology & $\begin{array}{l}\text { Hypertension } \\
\text { Anticoagulation }\end{array}$ & \\
\hline $\begin{array}{l}\text { Gastrointestinal and } \\
\text { hepatology }\end{array}$ & $\begin{array}{l}\text { Pediatric nutrition (enteral and parenteral) } \\
\text { Pediatric specific fluid and electrolyte balance } \\
\quad \text { (including dehydration management) }\end{array}$ & $\begin{array}{l}\text { Gastroesophageal reflux/Peptic ulcer disease } \\
\text { Nausea/Vomiting } \\
\text { Diarrhea } \\
\text { Constipation } \\
\text { Dose adjustments in liver dysfunction }\end{array}$ \\
\hline Nephrology & Drug dosing in renal dysfunction & $\begin{array}{l}\text { Acute renal failure } \\
\text { Chronic kidney disease }\end{array}$ \\
\hline Endocrine & & $\begin{array}{l}\text { Type } 1 \text { diabetes mellitus } \\
\text { Type } 2 \text { diabetes mellitus } \\
\text { Diabetic ketoacidosis and HHNS } \\
\text { SIADH } \\
\text { Thyroid disease }\end{array}$ \\
\hline $\begin{array}{l}\text { Hematology and } \\
\text { oncology }\end{array}$ & Leukemia/Lymphoma & $\begin{array}{l}\text { Anemia } \\
\text { Sickle cell disease } \\
\text { Supportive care }\end{array}$ \\
\hline $\begin{array}{l}\text { Immunology, } \\
\text { rheumatology, } \\
\text { and metabolic diseases }\end{array}$ & Rickets & $\begin{array}{l}\text { Food allergies } \\
\text { Familial hypercholesterolemia }\end{array}$ \\
\hline Infectious disease & $\begin{array}{l}\text { Upper respiratory tract infection (croup, pharyngitis) } \\
\text { Bronchiolitis } \\
\text { Pneumonia } \\
\text { Otitis media/Externa } \\
\text { Urinary tract infections (including prophylaxis) } \\
\text { Meningitis } \\
\text { Neonatal sepsis } \\
\text { Pediatric immunizations }\end{array}$ & $\begin{array}{l}\text { Head lice } \\
\text { Scabies } \\
\text { Pinworm } \\
\text { Cellulitis } \\
\text { Osteomyelitis/Septic arthritis } \\
\text { Sexually transmitted infections } \\
\text { Surgical prophylaxis } \\
\text { Influenza } \\
\text { Endocarditis }\end{array}$ \\
\hline Self-care & $\begin{array}{l}\text { Cough/Cold/Sore throat } \\
\text { Dermatitis (diaper, etc.) } \\
\text { Eczema }\end{array}$ & $\begin{array}{l}\text { Allergic rhinitis } \\
\text { Acne } \\
\text { Skin care (wounds, burns, etc) }\end{array}$ \\
\hline $\begin{array}{l}\text { Neonatal, obstetrics, } \\
\text { and reproductive }\end{array}$ & $\begin{array}{l}\text { Bronchopulmonary dysplasia and respiratory } \\
\text { distress syndrome } \\
\text { Routine neonatal care (vitamin K, etc.) } \\
\text { Drugs in pregnancy and lactation }\end{array}$ & Contraception \\
\hline
\end{tabular}




\section{American Journal of Pharmaceutical Education 2020; 84 (8) Article 7892.}

Table 2. Recommended Pharmacy Curricula Pediatric Topics to Be Included in Elective Pharmacy Courses for the Doctor of Pharmacy Program

\begin{tabular}{|c|c|}
\hline System & Elective Topics \\
\hline Neurology & $\begin{array}{l}\text { Cerebral palsy } \\
\text { Headache/migraine }^{\text {a }} \\
\text { Pain/Sedation }\end{array}$ \\
\hline Psychiatry & $\begin{array}{l}\text { Neonatal Abstinence Syndrome/Drug abuse }{ }^{\mathrm{a}} \\
\text { Bipolar/Schizophrenia - Pediatric-specific components and monitoring }\end{array}$ \\
\hline Pulmonology & Acute respiratory distress syndrome/Acute lung injury \\
\hline Cardiology & $\begin{array}{l}\text { Congenital heart disease/Heart failure } \\
\text { Acquired heart disease (Rheumatic and Kawasaki's) } \\
\text { Pediatric advanced life support } \\
\text { Pulmonary hypertension }^{\mathrm{a}}\end{array}$ \\
\hline Gastrointestinal and hepatology & $\begin{array}{l}\text { Inflammatory bowel disease }^{\mathrm{a}} \\
\text { Appendicitis }^{\mathrm{a}} \\
\text { Hyperbilirubinemia }_{\text {Hepatitis }^{\mathrm{a}}}\end{array}$ \\
\hline Nephrology & $\begin{array}{l}\text { Interstitial nephritis } \\
\text { Nephrotic syndrome } \\
\text { Hemolytic uremia } \\
\text { Polycystic kidney disease } \\
\text { Enuresis } \\
\text { Renal tubular acidosis }{ }^{\mathrm{a}}\end{array}$ \\
\hline Endocrine & $\begin{array}{l}\text { Adrenocortical insufficiency } \\
\text { Diabetes insipidus }\end{array}$ \\
\hline Hematology and oncology & $\begin{array}{l}\text { Hemophilia } \\
\text { Idiopathic thrombocytopenic purpura } \\
\text { Central nervous systemmalignancies } \\
\text { Hodgkin's and non-Hodgkin's disease } \\
\text { Neuroblastoma } \\
\text { Osteosarcoma } \\
\text { Disseminated intravascular coagulation } \\
\text { Rhabdomyosarcoma }\end{array}$ \\
\hline $\begin{array}{l}\text { Immunology, rheumatology, and metabolic } \\
\text { diseases }\end{array}$ & $\begin{array}{l}\text { Juvenile idiopathic arthritis } \\
\text { Systemic lupus erythematosus } \\
\text { Glycogen storage disease } \\
\text { Other inborn errors of metabolism } \\
\text { Phenylketonuria }\end{array}$ \\
\hline Infectious disease & $\begin{array}{l}\text { Pediatric sepsis/Septic shock } \\
\text { Parasitic infections }^{\mathrm{a}} \\
\text { Tuberculosis }^{\mathrm{a}} \\
\text { Pediatric HIV }\end{array}$ \\
\hline Self-care & Psoriasis $^{\mathrm{a}}$ \\
\hline $\begin{array}{l}\text { Neonatal, obstetrics, } \\
\text { and reproductive }\end{array}$ & $\begin{array}{l}\text { Retinopathy of prematurity } \\
\text { Intraventricular hemorrhage } \\
\text { Necrotizingenterocolitis } \\
\text { Patent ductusarteriosus } \\
\text { Apnea with bradycardia } \\
\text { Premature labor } \\
\text { Premature rupture of membranes } \\
\text { Pre-eclampsia/Eclampsia } \\
\text { Neonatal abstinence syndrome }\end{array}$ \\
\hline
\end{tabular}

${ }^{a}$ May be covered in adult-focused electives or by non-pediatric trained faculty (ID specialists,etc.) 


\section{American Journal of Pharmaceutical Education 2020; 84 (8) Article 7892.}

Table 3. Recommendations for Didactic and Experiential Pediatric Pharmacy Curricula for the Doctor of Pharmacy Program

Incorporate basic pediatric content with pediatric focused learning objectives throughout the required curriculum. Pediatric content should be taught by pediatric-trained faculty or content experts in specific fields of pharmacy. Include 30 to 50 hours of pediatric content to ensure an adequate level of competency.

Offer an elective course in pediatrics.

Integrate active-learning strategies into the pre-APPE pediatric pharmacy curriculum.

Ensure that each pharmacy graduate completes at least one pediatric focused APPE. When a pediatric APPE is not available, adapt APPE programs to allow the student to demonstrate competence in applying Level 3 or higher Entrustable Professional

Activities to pediatric patients.

Support concentrations in pediatric pharmacy.

and 2 provide a list of topics recommended for both the required and elective courses with pediatric subject matter. The intent of these recommendations is to include curricular incorporation as stand-alone topics and/or as a subtopic of primarily adult-focused topics in including, but not limited to, therapeutics, pharmacy practice laboratory, and/or integrated courses. For pharmacy students to reach the expected EPA competency level needed for pediatric patient care, the panel recommends that schools strive to include approximately 30 to 50 hours in the curriculum. In the instance that programs have a shortened curriculum, the panel supports investigating innovative ways to incorporate the suggested content.

Pharmacy programs must employ (or contract) pediatric-trained faculty/practitioners to teach pediatric content in the didactic curriculum (ACPE standard 10.6). Ideally, pediatric faculty members should have completed a PGY2 residency (or equivalent experience) and be board certified as a pediatric pharmacy specialist. ${ }^{20}$ Table 1 includes content that should be taught by pediatric-trained faculty members and content that may be taught by non-pediatric faculty members. The recommendations consider that there are significant differences in pathophysiology and pharmacotherapy for pediatric patients that may be missed if certain topics are covered only by adult practitioners. For example, many institutions employ faculty members specializing in cardiology, but pediatric and adolescent hypertension differs in origin, definition, and subsequent treatment options. For content areas that are similar between adult and pediatric patients, instruction by non-pediatric trained faculty members who are experts in a specific area of pharmacy, such as asthma and diabetes, can occur.

In addition to the required curriculum, ACPEaccredited institutions should offer a pediatrics elective course, preferably coordinated by pediatric-trained faculty members, to allow students interested in the field to expand their knowledge beyond those topics taught within the required curriculum (ACPE standard 10.9). When selecting topics for a pediatric elective, the course coordinator should evaluate the school's mission and primary goals along with the topics and teaching methodologies in the program's required and elective curriculum. The content of the elective should include "required" topics (Table 1) that were not incorporated into the standard curriculum, and time permitting, may include supplementary topics listed in Table 2. If the program has limited faculty members with the necessary expertise, the coordinator is encouraged to identify pediatric pharmacists or adjunct instructors with pediatric practice experience within their regions who have the knowledge and interest. For example, some institutions use APPE preceptors in elective courses, while others may contract with pediatric clinicians at a local children's hospital to educate students in the elective course.

The ACPE Standards 2016 stipulate that active learning be emphasized within the pharmacy school curricula. ${ }^{14}$ Active-learning pedagogies, which include but are not limited to problem-based learning (PBL), team-based learning (TBL), case-based instruction, and simulation-based learning, have been used to compliment lecture in pharmacy education and other higher education settings $^{21,22}$ and have been found to enhance pharmacy student learning and abilities. ${ }^{23-40}$ A 2013 survey of pediatric pharmacy education at pharmacy programs in the United States revealed that, although lecture is heavily relied on to teach pediatric content, the use of active learning is common. ${ }^{38}$ Case-based instruction was the most common active-learning pedagogy used (88\%), with TBL (34\%), PBL (30\%), and simulation (10\%) used more sparingly.

All pharmacy students are expected to apply clinical reasoning skills to patients of any age, and these skills should be assessed regularly throughout the curriculum (ACPE Standard 25.7). The integration of an activelearning pedagogy into pharmacy curricula to teach pediatric content may help accomplish this by providing students the opportunity to apply what they have learned and to develop the key attitudes and skills necessary to critically think through therapeutic and pharmaceutical 


\section{American Journal of Pharmaceutical Education 2020; 84 (8) Article 7892.}

care issues in the pediatric population. The inclusion of active-learning can be accomplished in a variety of ways, including but not limited to, pharmaceutical care laboratories focused on pediatric friendly dosage forms, administration techniques/dosing of medications to pediatric patients, nonprescription medication use in children, and effective communications skills when working with a child and his/her caregiver. However, because active learning may require a larger time commitment than other pedagogical approaches, strategic consideration must be given to its incorporation into the curriculum. All pharmacy programs should use some degree of active learning to teach pediatric topics in the curricula to enhance student learning. This can be accomplished through the following: integration of active-learning pedagogy into the didactic curriculum; provision of one or more immersive co-curricular activities focused on pediatrics within introductory pharmacy practice experiences (IPPEs); provision of one or more simulationbased learning exercises focusing on pediatrics prior to advancement to APPEs; or integration of one or more pediatric-focused objective structured clinical examinations (OSCEs) to provide a means to assess students' clinical reasoning skills in the area of pediatric pharmacy.

\section{Experiential Education}

Enhanced pre-APPE pediatric curricular content affords students the opportunity to build a solid foundation to achieve both specialized competencies and milestone EPAs. Both IPPEs and APPEs have long been established as integral components of the curriculum and now serve as practical opportunities for students to meet all levels of EPAs. However, it is imperative that these EPAs include pediatric competencies for all pharmacy graduates. Pharmacy programs should offer IPPEs and APPEs structured to allow exposure to pediatric patients, among other diverse populations (ACPE Standard 10.9 and 13.2), through which students will advance from level 1 activities to level 3 by graduation.

To elevate pediatric pharmacy education and the level of EPAs, the panel strongly recommends that each PharmD student complete at least one pediatric-focused APPE. This recommendation is consistent with the recommendations of the previous working group. ${ }^{1}$ In a survey of US pharmacy programs, IPPEs and APPEs in pediatrics are offered by $53 \%$ and $97 \%$ of institutions, respectively. Even though many programs have pediatricfocused rotation experiences available, only $20 \%$ of PharmD students completed at least one, most likely the consequence of an insufficient supply of these APPEs at most pharmacy schools. ${ }^{13}$ When no pediatric-focused APPEs are available, the following are potential solutions:
(1) identify rotation experiences that are not pediatricfocused but do include provision of care to pediatric patients (eg, emergency departments, family medicine clinics); (2) consider a "co-preceptor" model that includes interprofessional education and use of faculty members or adjunct faculty members to provide basic tenants (eg, the student accompanies a pediatric hospitalist on daily rounds and meets with a pharmacy faculty member on a daily basis to discuss pediatric patients and topics); (3) develop and maintain a pediatric reference library for use by students during APPEs, regardless of the type of rotation experience. For pharmacy schools where there is a limited availability of pediatric-focused APPEs, this panel recommends that students should have, at minimum, the opportunity to achieve level 3 EPAs for a pediatric patient in each of the following domains: patient care provider, interprofessional team member, population health promoter, information master, and practice manager. As a baseline requirement, students shall be able to demonstrate level 3 competency in fulfilling a pediatric medication order as outlined in the practice manager domain. Table 4 offers an example of incorporating both low- and high-level EPAs in pediatric care, which can be used in each of the three solutions mentioned above.

\section{Pediatric Pharmacy Concentrations}

With the expansion of pharmacy practice opportunities across the United States, several pharmacy programs have developed curricular tracks for students to focus on a specific pharmacy practice area. ${ }^{41-43}$ The goal of these tracks may vary among pharmacy programs, but in general, the intention is to prepare students for postgraduate opportunities (eg, residency and fellowship) and board certification, provide exposure to clinical research, and offer a concentrated experience in a specific patient care area. As mentioned previously, students receive a median of 16 hours of pediatric content in their pharmacy curricula, and only $20 \%$ of students complete a pediatric APPE. ${ }^{38}$ Based on these data, graduates of pharmacy programs who have an interest in pediatrics may not be prepared for entry-level positions in children's hospitals and a curricular track in pediatrics offers a mechanism for exposing students to core competencies required of clinical pharmacists caring for this vulnerable population. $^{44-49}$

A few pharmacy programs have developed pediatric curricular tracks. ${ }^{49,50}$ Pediatric curricular tracks provide students with depth of training in pediatrics, generally offering opportunities for students to complete at least one didactic elective in pediatric pharmacy, an independent study involving pediatric research, and at least one pediatric APPE. ${ }^{50}$ The clinical knowledge and problem-solving 


\section{American Journal of Pharmaceutical Education 2020; 84 (8) Article 7892.}

Table 4. Example Progression of Entrustable Professional Activities for Pediatric Immunizations for the Doctor of Pharmacy Program

\begin{tabular}{|c|c|c|c|}
\hline $\begin{array}{l}\text { Core Entrustable } \\
\text { Professional Activities } \\
\text { (Patient Care Provider } \\
\text { Domain) }\end{array}$ & $\begin{array}{c}\text { Pediatric } \\
\text { Immunizations }\end{array}$ & IPPE & APPE \\
\hline $\begin{array}{l}\text { Collect information to identify } \\
\text { a patient's medication- } \\
\text { related problems and } \\
\text { health-related needs }\end{array}$ & $\begin{array}{l}\text { Properly assess } \\
\text { immunization } \\
\text { history }\end{array}$ & $\begin{array}{l}\text { Observe a pharmacist obtaining } \\
\text { a vaccination history for a } \\
\text { pediatric patient from a } \\
\text { caregiver and/or an online } \\
\text { vaccine registry (Level 1) and } \\
\text { then doing the same with } \\
\text { supervision (Level 2) }\end{array}$ & $\begin{array}{l}\text { Interview the caregiver and/or } \\
\text { patient to determine if any } \\
\text { contraindications to vaccination } \\
\text { exist (allergies, etc.) (Level } 3 \text { or } \\
\text { higher?) }\end{array}$ \\
\hline $\begin{array}{l}\text { Establish patient-centered } \\
\text { goals and create a care } \\
\text { plan for a patient in } \\
\text { collaboration with the } \\
\text { patient, caregiver(s), and } \\
\text { other health professionals } \\
\text { that is evidence-based and } \\
\text { cost-effective }\end{array}$ & $\begin{array}{l}\text { Interpret the } \mathrm{CDC}^{\mathrm{a}} \\
\text { vaccination schedule } \\
\text { and provide } \\
\text { recommendations } \\
\text { based on age and } \\
\text { history }\end{array}$ & $\begin{array}{l}\text { Identify the CDC vaccination } \\
\text { schedule for children and } \\
\text { determine which vaccines the } \\
\text { child needs (Level 1-2) }\end{array}$ & $\begin{array}{l}\text { Recommend which vaccines the } \\
\text { child should receive and } \\
\text { determine the appropriate route, } \\
\text { needle size, and administration } \\
\text { site (Level } 3 \text { or higher) }\end{array}$ \\
\hline $\begin{array}{l}\text { Implement a care plan in } \\
\text { collaboration with the } \\
\text { patient }\end{array}$ & $\begin{array}{l}\text { Administer } \\
\text { vaccinations }\end{array}$ & \multicolumn{2}{|c|}{$\begin{array}{l}\text { Where allowed by state law, administer vaccinations to a child under the } \\
\text { supervision of a licensed pharmacist (Level 4-5) }\end{array}$} \\
\hline $\begin{array}{l}\text { Follow-up and monitor a } \\
\text { care plan }\end{array}$ & $\begin{array}{l}\text { Monitor the patient for } \\
\text { adverse reactions to } \\
\text { vaccines; Develop } \\
\text { plan for follow-up } \\
\text { vaccines }\end{array}$ & $\begin{array}{l}\text { Determine what monitoring } \\
\text { parameters are appropriate for } \\
\text { the immunizations that are } \\
\text { being administered; Determine } \\
\text { when follow-up vaccines (eg, } \\
\text { booster doses) should be } \\
\text { administered (Level 1-2) }\end{array}$ & $\begin{array}{l}\text { Monitor the patient for applicable } \\
\text { adverse reactions and counsel } \\
\text { the patient and caregiver on any } \\
\text { potential adverse reactions; } \\
\text { Communicate follow-up plan } \\
\text { and rationale to caregiver and/ } \\
\text { or healthcare provider (Level 4-5) }\end{array}$ \\
\hline
\end{tabular}

${ }^{\mathrm{a}} \mathrm{CDC}=$ Centers for Disease Control

skills gained in caring for a pediatric patient through these curricular tracks can be applied to a variety of practice settings in the community or health-system setting and are not limited to students seeking pediatric clinical specialist positions. Two programs that have a pediatric curricular track found that $40 \%-66.7 \%$ of PharmD graduates who chose the track went on to complete a PGY1 residency at an institution that specialized in pediatrics or that offered several pediatric rotations. ${ }^{50,51}$ Although pharmacy programs may find development and maintenance of concentrations difficult because of limited faculty time and resources, curricular tracks may better prepare students for postgraduate training and pediatric board certification or may better qualify and equip them for entry-level positions in children's hospitals.

\section{CONCLUSION}

Pharmacy education must account for care across the lifespan, increased medication safety risks in pediatrics, and application of limited pediatric information despite continued drug discovery and innovation. To ensure provision of safe and effective care to this special population, it is important for schools and colleges of pharmacy to make certain that all pharmacy graduates are competent for entry-level positions in which they will care for pediatric patients, whether that is in residency training, a small community hospital, or a community pharmacy. Future accreditation standards can assist in incorporating these pediatric competencies.

\section{ACKNOWLEDGMENTS}

This paper represents the opinion of the Pediatrics Practice and Research Network of the American College of Clinical Pharmacy (ACCP), the Pediatric Pharmacy Association (PPA), and the American Association of Colleges of Pharmacy (AACP) Pediatric Pharmacy Special Interest Group. It does not necessarily represent an official ACCP or AACP commentary, guideline, or statement of policy or position. 


\section{American Journal of Pharmaceutical Education 2020; 84 (8) Article 7892.}

\section{REFERENCES}

1. Aucoin RB, Buck ML, Dupuis LL, Dominguez KD, Smith KP. Pediatric pharmacotherapeutic education: current status and recommendations to fill the growing need. Pharmacotherapy. 2005;25(9):1277-1282.

2. Federal Interagency Forum on Child and Family Statistics. POP2 children as a percentage of the population: persons in selected age groups as a percentage of the total U.S. population, and children ages 0-7 as a percentage of the dependent population, 1950-2016 and projected 2017-2050. https://www.childstats.gov/americaschildren/ tables/pop2.asp. Accessed August 6, 2020.

3. National Center for Health Statistics. Health, United States, 2016: With Chartbook on long-term trends in health. Hyattsville, MD. 2017. https://www.cdc.gov/nchs/data/hus/hus16.pdf. Accessed August 6, 2020.

4. Rui P, Okeyode T. National Ambulatory Medical Care Survey: 2015 State and National Summary Tables. https://www.cdc.gov/ nchs/data/ahcd/namcs_summary/2015_namcs_web_tables.pdf. Accessed August 6, 2020.

5. McClead RE, Catt C, Davis JT, et al. An internal quality improvement collaborative significantly reduces hospital-wide medication error related adverse drug events. J Pediatr. 2014;165: 1222-1229.

6. Fondren ME, Desselle SP. The fate of pediatric prescriptions in community pharmacies. J Patient Saf. 2015;11(2):79-88.

7. Institute of Medicine (2012). Safe and Effective Medicines for

Children: Pediatric Studies Conducted Under the Best

Pharmaceuticals for Children Act and the Pediatric Research Equity Act. Washington, DC: The National Academies Press. https://doi.org/ 10.17226/13311. Accessed August 6, 2020.

8. Califf RM. Best Pharmaceuticals for Children Act and Pediatric Research Equity Act: July 2016 Status Report to Congress. https:// www.fda.gov/downloads/ScienceResearch/SpecialTopics/

PediatricTherapeuticsResearch/UCM509815.pdf. Accessed August 6,2020 .

9. Food and Drug Administration Safety and Innovation Act: July 9, 2012. https://www.govinfo.gov/content/pkg/PLAW-112publ144/pdf/ PLAW-112publ144.pdf. Accessed August 6, 2020.

10. Civic Impulse, LLC. S.456: RACE for children act [internet monograph]. Civic Impulse, LLC. February 27, 2017. https://www. govtrack.us/congress/bills/115/s456. Accessed August 6, 2020.

11. American Academy of Pediatrics Committee on Drugs. Off-label use of drugs in children. Pediatrics. 2014;133(3):563-7.

12. Green DJ, Burkhart GJ. Pediatric drug development: outlook for science-based innovation. Clinical Pharmacology and Therapeutics. 2018;103:376-378.

13. Prescott WA Jr, Dahl EM, Hutchinson DJ. Education in pediatrics in US colleges and schools of pharmacy. Am J Pharm Educ. 2014;78(3):Article 51.

14. Accreditation Council for Pharmacy Education. Accreditation standards and guidelines for the professional program in pharmacy leading to the doctor of pharmacy degree. Chicago, IL: Accreditation Council for Pharmacy Education, 2015. https://www.acpeaccredit.org/pdf/Standards2016FINAL.pdf. Accessed June 6, 2018. 15. Medina MS, Plaza CM, Stowe CD, et al. Center for the Advancement of Pharmacy Education 2013 Educational Outcomes. Am J Pharm Educ. 2013:77(8):Article 162.

16. American Society of Health-System Pharmacists (2016).

Required competency areas, goals, and objectives for post-graduate year two (PGY2) pediatric pharmacy residencies [internet monograph]. Bethesda, MD: American Society of Health-System
Pharmacists. https://www.ashp.org/Professional-Development/ Residency-Information/Residency-Program-Resources/ResidencyAccreditation/PGY2-Competency-Areas. Accessed August 6, 2020. 17. American College of Clinical Pharmacy, Schwinghammer TL, Crannage AJ, et al. 2016 ACCP Pharmacotherapy Didactic Curriculum Toolkit. https://www.accp.com/docs/positions/misc/ Toolkit_final.pdf. Accessed August 6, 2020.

18. Pittenger AL, Copeland DA, Lacroix MM, et al. Report of the 2016-2017 Academic Affairs Standing Committee: entrustable professional activities implementation roadmap. Am J Pharm Educ. 2017;81(5):S4.

19. Association of American Medical Colleges. 2014. Core entrustable professional activities for entering residency: faculty and learners' guide. https://www.aamc.org/initiatives/coreepas. Accessed August 6, 2020.

20. Saseen JJ, Ripley TL, Bondi D, et al. ACCP clinical pharmacist competencies. Pharmacotherapy. 2017;37(5):630-636.

21. Means B, Toyama Y, Murphy R, Bakia M, Jones K. Evaluation of evidence-based practices in online learning: A meta-analysis and review of online learning studies. Washington, DC: U.S. Department of Education, Office of Planning, Evaluation, and Policy

Development, 2010. https://www2.ed.gov/rschstat/eval/tech/ evidence-based-practices/finalreport.pdf. Accessed August 6, 2020. 22. Gleason BL, Peeters MJ, Resman-Targoff BH, et al. An activelearning strategies primer for achieving ability-based educational outcomes. Am J Pharm Educ. 2011;75(9):Article 186.

23. Romero RM, Erikson SP, Haworth IS. A decade of teaching pharmaceutics using case studies and problem-based learning. Am J Pharm Educ. 2004;68(2):Article 31.

24. Hogan S, Lundquist M. The impact of problem-based learning on students' perceptions of preparedness for advanced pharmacy practice experiences. Am J Pharm Educ. 2006;70(4):Article 82. 25. Westberg SM, Adams J, Thiede K, Stratton TP, Bumgardner MA. An interprofessional activity using standardized Patients. Am J Pharm Educ. 2006;70:Article 34.

26. Ross LA, Crabtree BL, Theilman GD, Ribeiro LM, Pereira MG. Implementation and refinement of a problem-based learning model: A ten-year experience. Am J Pharm Educ. 2007;71(1):Article 17. 27. Seybert AL, Barton CM. Simulation-based learning to teach blood pressure assessment to doctor of pharmacy students. Am J Pharm Educ. 2007;71:Article 48.

28. Letassy NA, Fugate SE, Medina MS, Stroup JS, Britton ML. Using team-based learning in an endocrine module taught across two campuses. Am J Pharm Educ. 2008;72(5):Article 103.

29. Seybert AL, Kobulinsky LR, McKaveney TP. Human patient simulation in a pharmacotherapy course. Am J Pharm Educ. 2008; 72:Article 37.

30. Beatty SJ, Kelley KA, Metzger AH, Bellebaum KL, McAuley JW. Team-based learning in therapeutics workshop sessions. Am J Pharm Educ. 2009;73(6):Article 100.

31. Conway SE, Johnson JL, Ripley TL. Integration of team-based learning strategies into a cardiovascular module. Am J Pharm Edu.c 2010;74(2):Article 35.

32. Romero RM, Erikson SP, Haworth IS. Quantitative assessment of assisted problem-based learning in a pharmaceutics course. Am J Pharm Educ. 2010;74(4):Article 66.

33. Strohfeldt K, Grant DT. A model for self-directed problem-based learning for renal therapeutics. Am J Pharm Educ. 2010;74(9):Article 173. 34. Donohoe KL, Mawyer TM, Stevens JT, Morgan LA, Harpe SE. An active-learning laboratory on immunizations. Am J Pharm Educ. 2012:76(10):Article 198. 


\section{American Journal of Pharmaceutical Education 2020; 84 (8) Article 7892.}

35. Nicholl TA, Lou K. A model for small-group problem-based learning in a large class facilitated by one instructor. Am J Pharm Educ. 2012;76(6):Article 117.

36. Condren ME, Honey BL, Nguyen V, Carson S. Pediatric medication safety training for doctor of pharmacy students [abstract]. Am J Pharm Educ. 2013:77(5):Article 109.

37. McFall M. Integration of problem-based learning and innovative technology into a self-care course. Am J Pharm Educ. 2013;77(6): Article 127.

38. Prescott WA Jr., Woodruff A, Prescott GM, et al. Design and assessment of a blended-learning model integrating team- and casebased learning to teach patient assessment skills in a PharmD program. Am J Pharm Educ. 2016;80(10):Article 176.

39. Fernandez R, Parker D, Kalus JS, Miller D, Compton S. Using a human patient simulation mannequin to teach interdisciplinary team skills to pharmacy students. Am J Pharm Educ. 2007;71(3):Article 51. 40. Hutchinson AM, Eiland LS. Incorporating age-related special populations into a pharmacy skills laboratory course sequence. Curr Pharm Teach Learn. 2017;9(5):821-827.

41. New J, Garner S, Ragucci K, Spencer A. An advanced clinical track within a doctor of pharmacy program. Am J Pharm Educ. 2012;76(5):Article 43.

42. Surratt CK, Drennen JK, Bricker JD. The "Research Tack" concentration, a new PharmD elective option. Am J Pharm Educ. 2005;69(5):90:1-6.

43. Brahm NC, Davis TS. Development of a psychiatric pharmacy elective track. Curr Pharm Teach Learn. 2012;267-272.

44. Bhatt-Mehta V, Buck ML, Chung AM, et al. Recommendation for meeting the pediatric patient's need for a clinical pharmacist: a joint opinion of the Pediatric Practice and Research Network of the American College of Clinical Pharmacy and the Pediatric Pharmacy Advocacy Group. Pharmacotherapy. 2013:33:243-251.

45. Boucher EA, Burke MM, Johnson PN, Klein KC, Miller JL. Minimum requirements for core competency in pediatric pharmacy practice. J Pediatr Pharmacol Ther. 2015;20:481-484.

46. Board of Pharmacy Specialties. Pediatric pharmacy fact sheet [internet monograph]. Washington, DC: Board of Pharmacy Specialties. http://www.bpsweb.org/wp-content/uploads/ factsheet_pediatric.pdfAccessed August 6, 2020.

47. Sorensen TD, Shapiro NL, Benedict N, et al. Recommendations for aligning PGY2 pharmacy residency training and pharmacy specialist board certification. Pharmacotherapy. 2016;36: e34-e39.

48. Joint Commission of Pharmacy Practitioners. Vision for pharmacists' practice. Joint Commission of Pharmacy Practitioners. https://jcpp.net/wp-content/uploads/2016/02/JCPP-VisionSlide.pptx. Accessed August 6, 2020.

49. Condren ME, Haase MR, Luedtke SA, Gaylor AS. Clinical activities of an academic pediatric pharmacy team. Ann Pharmacother. 2004:38:574-578.

50. Johnson PN, Gildon BL, Condren M, et al. Description of a pediatric degree option program in a doctorate of pharmacy curriculum and its impact on pediatric-focused advanced pharmacy practice experience rotations and faculty scholarly productivity. Curr Pharm Teach Learn. 2018;10:627-636.

51. Russell HA, Lubsch L, Nelson M. The design and evaluation of a pediatric specialization at a school of pharmacy [abstract]. $J$ Pediatr Pharmacol Ther. 2015;20(3):222-255. 